\title{
Should International Organizations Include Beneficiaries in Decision- making? Arguments for Mediated Inclusion
}

\begin{abstract}
There are longstanding calls for international organizations (IOs) to be more inclusive of the voices and interests of people whose lives they affect. There is nevertheless widespread disagreement among practitioners and political theorists over who ought to be included in IO decision-making and by what means. This paper focuses on the inclusion of IOs' 'intended beneficiaries,' both in principle and practice. It argues that IOs' intended beneficiaries have particularly strong normative claims for inclusion because IOs can affect their vital interests and their political agency. It then examines how these claims to inclusion might be feasibly addressed. The paper proposes a model of inclusion via representation and communication, or 'mediated inclusion.' An examination of existing practices in global governance reveals significant opportunities for the mediated inclusion of IOs' intended beneficiaries, as well as pervasive obstacles. The paper concludes that the inclusion of intended beneficiaries by IOs is both appropriate and feasible.
\end{abstract}

Keywords: global governance; international organizations; democratic deficit; inclusion; affected interests.

\section{Introduction}

In recent decades, there have been widespread demands for international organizations (IOs) to be more accountable and responsive to the individuals and groups they affect. ${ }^{1}$ These demands are provoked by questions about the normative legitimacy of IO governance, as well as by examples of IO actions that have caused harm and disempowerment. Scholars and practitioners have called for reforms of IO decision-making to make it more inclusive of 'stakeholders' such as civil society organizations, private businesses and epistemic communities. This paper examines the normative claims and the feasibility of inclusion for one type of stakeholder, IOs' 'intended beneficiaries.'

By 'intended beneficiaries,' I refer to the categories of people whose interests are meant to be advanced by IOs, and whose plights are used to justify the existence, authority and actions of IOs. ${ }^{2}$ Importantly, the social categories of intended beneficiaries are to some degree constituted by IOs. For instance, the

1 By 'international organizations' I refer to intergovernmental organizations. This paper's normative argument applies to other global governance institutions with categories of intended beneficiaries, but feasible mechanisms for their inclusion may differ.

2 For a similar definition of intended beneficiaries, see Mathias Koenig-Archibugi and Kate Macdonald, 'The Role of Beneficiaries in Transnational Regulatory Processes', The ANNALS of the American Academy of Political and Social Science 670/1 (2017), 36-57, p. 37. 
United Nations High Commissioner for Refugees (UNHCR) helps define the category of 'refugees,' targets them for assistance and governance, and wields authority as both the champion of refugees and as an institution that states have authorized to manage problems of international migration. ${ }^{3}$ The UNHCR and other IOs are frequently celebrated for the assistance they provide, but they are also criticized for harming or disempowering the people they ought to benefit. Such criticisms have prompted attention to causes and remedies, including calls for greater influence in IOs' decision-making. ${ }^{4}$ This paper develops that argument.

The first section sets out my normative framework for inclusion and applies it to IOs' intended beneficiaries. By 'inclusion,' I mean that people have the opportunities and capabilities to ensure that their views and interests are taken into account in decision-making. I build on the principle of affected interests, as developed in recent democratic theory, which holds that those affected by governance warrant inclusion. I argue that people can make stronger claims for inclusion if institutions may affect their vital interests or appropriate their political agency. These additional dimensions of affectedness can be seen in IOs' relationships to their intended beneficiaries.

In the second section I propose that the inclusion of intended beneficiaries in IOs' decision-making should, to a significant extent, be pursued through processes of representation and communication. This 'mediated inclusion' is appropriate for large-scale governance in which direct participation is rarely feasible. Mediated inclusion of a constituency is successful when three components come together. First, constituencies require representatives who can make strong claims to speak on their behalves. Second, these representatives must have meaningful opportunities to influence decision-making. Third, decision-making must be made in a sufficiently public manner.

The next three sections examine each of these components in turn, looking at current practices in IOs' relationships with their intended beneficiaries. This analysis reveals institutional experimentation and some promising trends across IOs, as well as pervasive obstacles to inclusion.

The paper concludes that the mediated inclusion of IOs' intended beneficiaries is both appropriate and feasible.

3 Michael Barnett and Martha Finnemore, Rules for the World: International Organizations in Global Politics (Ithaca, N.Y.: Cornell University Press, 2004); Michael Barnett, 'Humanitarianism, Paternalism, and the UNHCR', in Alexander Betts and Gil Loescher, (eds.), Refugees in International Relations (Oxford: Oxford University Press, 2011), 105-32.

4 Barnett (2011); Thomas Carothers and Saskia Brechenmacher, 'Accountability, Transparency, Participation, and Inclusion: A New Development Consensus?’, (Washington, DC: Carnegie Endowment for International Peace, 2014); Koenig-Archibugi and Macdonald (2017). 


\section{The Affected Interests Principle and International Organizations}

Democratic theorists argue that existing structures and practices of global governance often fall short of democratic standards. As a result, IOs and other global governance institutions may violate normative commitments and practical goods associated with democracy. ${ }^{5}$ In this paper I focus on the democratic principle of inclusion, and on questions about who ought to be included in decision-making by global governance institutions, on what grounds, and through what mechanisms. ${ }^{6}$

To address these questions, I build on what democratic theorists refer to as the 'affected interests' principle (AIP). ${ }^{7}$ I argue that framing the issue of inclusion using the AIP helps to (a) identify the potential scope of normatively desirable inclusions, (b) clarify the relative strength of the claims to inclusion by people affected differently, and (c) justify the development of feasible mechanisms to include certain constituencies in relevant decision-making processes.

According to the AIP, those people who are significantly affected by governance decisions have a normative claim to inclusion in that decision-making. In recent years, democratic theorists have used the AIP to diagnose democratic deficits in global governance and formulate remedies to them. The AIP is a significant departure from a conventional emphasis on membership in a state as the sole justification for democratic inclusion. The principle has been criticized on both philosophical and practical grounds, and democratic theorists have put forward alternate principles. ${ }^{8}$ It is beyond the scope of this article to justify the AIP or defend it against alternatives. However, I use the AIP in a way that may make it more acceptable to some of its critics.

5 Klaus Dingwerth, 'Global Democracy and the Democratic Minimum: Why a Procedural Account Alone Is Insufficient', European Journal of International Relations 20/4 (2014), 1124-47; Jonathan W. Kuyper and Theresa Squatrito, 'International Courts and Global Democratic Values: Participation, Accountability, and Justification', Review of International Studies 43/1 (2016), 152-76; Michael Zürn, 'Global Governance and Legitimacy Problems', Government and Opposition 39/2 (2004), 260-87.

6 Inclusion is not the only normative principle for democracy but a critical one. See Mark E. Warren, 'A ProblemBased Approach to Democratic Theory', American Political Science Review 111/1 (2017), 39-53; Iris Marion Young, Inclusion and Democracy (Oxford: Oxford University Press, 2000).

7 Archon Fung, 'The Principle of Affected Interests: An Interpretation and Defense', in Jack H Nagel and Rogers M Smith, (eds.), Representation: Elections and Beyond (Philadelphia: University of Pennsylvania Press, 2013), 23668; Robert E. Goodin, 'Enfranchising All Affected Interests, and Its Alternatives', Philosophy \& Public Affairs 35/1 (2007), 40-68; Mathias Koenig-Archibugi, 'How to Diagnose Democratic Deficits in Global Politics: The Use of the 'All-Affected Principle”, International Theory 9/2 (2017), 171-202; David Owen, 'Constituting the Polity, Constituting the Demos: On the Place of the All Affected Interests Principle in Democratic Theory and in Resolving the Democratic Boundary Problem', Ethics \& Global Politics 5/3 (2012), 129-52.

8 For the argument that inclusion is justified by subjection, see Arash Abizadeh, 'On the Demos and Its Kin: Nationalism, Democracy, and the Boundary Problem', American Political Science Review 106/04 (2012), 867-82; Nancy Fraser, Scales of Justice: Re-Imagining Political Space in a Globalizing World (New York: Columbia University Press, 2009). For the argument that the state remains the appropriate polity for claims to democratic inclusion, see Sarah Song, 'The Boundary Problem in Democratic Theory: Why the Demos Should Be Bounded by the State', International Theory 4 (2012), 39-68. 
First, I do not argue that all possibly or slightly affected people can make normative claims to inclusion. ${ }^{9}$ Rather, I follow those who propose that inclusion in governance decision-making is warranted when people's interests and capabilities are likely to be deeply affected. ${ }^{10}$ Second, I propose that affectedness generates a normative claim to inclusion in the particular global governance decision-making processes that determine that affectedness. I do not propose that affectedness generates a normative claim to full and equal inclusion in a strong global demos, a possible implication of AIP that concerns some democratic theorists on practical and philosophical grounds. ${ }^{11}$ Third, I do not argue that inclusion is the only democratic principle that should inform global governance, and I agree with those who also call for principles of accountability, political equality and public justification. ${ }^{12}$ Finally, I share concerns about the feasibility of the application of the AIP to global governance, and the possibility that inclusions justified by the principle may be unworkable in practice. I therefore propose a viable and normatively-defensible means for inclusion: the mediated inclusion of affected constituencies via representation. I then provide evidence that mediated inclusion is feasible for constituencies that have strong claims to inclusion according to the AIP: the intended beneficiaries of IOs.

As Fung and others have argued, including people in decisions that affect them both respects their autonomy (an inherent democratic principle) and creates opportunities for people to protect their important interests (a consequential good). ${ }^{13}$ To best achieve these inherent and consequential aims, those who are more significantly affected by governance institutions have stronger normative claims to inclusion. ${ }^{14}$ Furthermore, narrowing the scope of claims to inclusion to those who are significantly affected will reduce the number of possible claimants and thus the organizational burdens of facilitating inclusion. I agree with these arguments. However, I argue that evaluations of affectedness in the application of AIP need to be modified through two further considerations.

First, those whose vital interests or basic capabilities for agency are at stake in governance outcomes ought to be able to make stronger normative claims to inclusion. This complement to the AIP helps to address possible problems

9 For this formulation, which is rarely endorsed by defenders of the AIP, see Goodin (2007).

10 Carol C Gould, Globalizing Democracy and Human Rights (Cambridge: Cambridge University Press, 2004); KoenigArchibugi (2017).

11 David Miller, 'Democracy's Domain', Philosophy and Public Affairs 37/3 (2009), 201-28; Song (2012).

12 Dingwerth (2014); Kuyper and Squatrito (2016); Terry Macdonald, Global Stakeholder Democracy: Power and Representation Beyond Liberal States (Oxford: Oxford University Press, 2008).

13 Fung (2013).

14 Fung (2013), p. 263; Laura Valentini, 'No Global Demos, No Global Democracy? A Systematization and Critique', Perspectives on Politics 12/04 (2014), 789-807, p. 795. 
of inequity. ${ }^{15}$ For instance, if inclusion is simply linked to the extent of affectedness, the AIP may prioritize inclusion for those whose inclusion could help them secure the largest material gains.

Second, stronger claims to inclusion can be made by those groups that are constituted as constituencies by governance institutions, and whose political agency is potentially appropriated by those institutions. ${ }^{16}$ This consideration brings attention to wrongful infringements of autonomy that can be missed by accounts that focus too narrowly on consequential interests.

This modified version of the AIP can be used to identify specific groups with particularly strong claims to inclusion in global governance decision-making, as I will show through an analysis of IOs and their intended beneficiaries.

\section{Claims to Inclusion by IOs'Intended Beneficiaries}

International organizations may affect the interests of various state and non-state actors, including private businesses, communities of experts, and the citizens of member states. Scholars frequently examine the involvement of these and other stakeholder groups in IO decision-making without distinguishing their different normative claims to inclusion. I argue IO's 'intended beneficiaries' have stronger claims to inclusion than other stakeholder groups. Efforts to improve inclusion at IOs should therefore prioritize their intended beneficiaries.

By the 'intended beneficiaries' of IOs I refer to those categories of people whose interests those IOs are meant to advance. As scholars have argued, IOs and their intended beneficiaries are to a significant extent co-constituted. Many IOs help to designate and shape the categories of intended beneficiaries, and the IOs would not exist without these categories of people to justify their existence and authority. For instance, it is impossible to have the UNHCR without 'refugees, ${ }^{17}$ or the International Criminal Court (ICC) without 'victims of international crimes. ${ }^{18}$ This constitutive power of IOs has also been shown in the social construction of intended beneficiaries such as trafficked persons, ${ }^{19}$

15 Thanks to Mark Warren for this point. See Mark E. Warren, 'The All Affected Interests Principle in Democratic Theory and Practice', APSA Annual Conference (San Francisco, 2017).

16 Smith makes an analogous argument, claiming that constitutional democratic states must provide full inclusion to people whose thick political identities are constituted by the state (Rogers M Smith, 'The Principle of Constituted Identities and the Obligation to Include', Ethics \& Global Politics 1/3 (2008), 139-53).

17 Barnett and Finnemore (2004), p. 73-120; Barnett (2011).

18 Peter Dixon and Chris Tenove, 'International Criminal Justice as a Transnational Field: Rules, Authority and Victims', International Journal of Transitional Justice 7/3 (2013), 393-412.

19 Kristina Hahn, 'NGOs' Power of Advocacy: The Construction of Identities in UN Counter-Human Trafficking Policies", in Jens Steffek and Kristina Hahn, (eds.), Evaluating Transnational NGOs: Legitimacy, Accountability, Representation (New York: Palgrave Macmillan, 2010), 220-41. 
the global poor, ${ }^{20}$ and 'civilians' deserving of protection in conflict. ${ }^{21}$ Not all IOs have such categories of intended beneficiaries, but a significant subset does. ${ }^{22}$

When the modified version of the affected interests principle is used to analyze the relationships of IOs with intended beneficiaries, the strength of their normative claims to inclusion becomes clear.

First, IOs often define their intended beneficiaries in ways that foreground their vital interests, as in 'refugees' or 'victims of international crimes' or the 'global poor.' ${ }^{23}$ If the actions of IOs always improved the vital interests of intended beneficiaries, then inclusion might not be necessary. However, research suggests that this is not the case. IOs frequently pursue aims other than the interests of their beneficiaries, particularly in the absence of processes for beneficiary populations to direct policy directions and hold institutions to account. ${ }^{24}$ Furthermore, IOs can also interfere in their intended beneficiaries' own actions to protect or advance their interests. For instance, peacekeepers have been shown to sometimes undermine civilians' self-protection strategies or crowd out local peacebuilding efforts, ${ }^{25}$ and UNHCR policies have sometimes led to people being 'warehoused' in refugee camps, where they may face greater exposure to violence and greater obstacles to productive economic activity or integration into new societies. ${ }^{26}$

Second, IOs help to constitute their intended beneficiaries as transnational constituencies that ground political claims, and often make claims to govern or speak on behalf of these constituencies. IO officials often make claims about the needs, aims and perspectives of intended beneficiaries such as refugees, the global poor, and the victims of international crimes in international and domestic political forums, and derive legitimacy and resources by doing so. ${ }^{27}$ The constitution of transnational constituencies of intended beneficiaries

20 Suzan Ilcan and Anita Lacey, Governing the Poor: Exercises of Poverty Reduction, Practices of Global Aid (Montreal \& Kingston: McGill-Queen's University Press, 2011).

21 Charli Carpenter, "Women, Children and Other Vulnerable Groups": Gender, Strategic Frames and the Protection of Civilians as a Transnational Issue', International Studies Quarterly 49/2 (2005), 295-334.

22 Not all IOs have single categories of intended beneficiaries. The UN, for instance, has a variety of specialized agencies, some of which focus on different categories of beneficiaries, such as the UNHCR and the UN Children's Fund.

23 Not all IOs foreground intended beneficiaries whose vital interests are at stake. For instance, the World Tourism Organization (UNWTO) may affect the lives of tourists and those engaged in tourism economies but its actions do not focus on their vital interests. However, the UNWTO does seek to foster tourism initiatives to assist those facing extreme poverty, and such groups should arguably be included in relevant decision-making.

24 Barnett and Finnemore (2004); Koenig-Archibugi and Macdonald (2017); Jan Aart Scholte, Building Global Democracy?: Civil Society and Accountable Global Governance (Cambridge: Cambridge University Press, 2011).

25 Séverine Autesserre, Peaceland: Conflict Resolution and the Everyday Politics of International Intervention (Cambridge: Cambridge University Press, 2014).

26 Merrill Smith, 'Warehousing Refugees', World Refugee Survey (Washington, DC: US Committee for Refugees, 2004), 38-56; Guglielmo Verdirame and Barbara E Harrell-Bond, Rights in Exile: Janus-Faced Humanitarianism (Oxford: Berghahn Books, 2005).

27 See for example Barnett and Finnemore (2004); Dixon and Tenove (2013). 
can be positive, but can also enable IOs to usurp or appropriate the symbolic status of these groups. ${ }^{28}$ The risk that powerful actors' may appropriate the status and voices of disadvantaged groups is well-studied. ${ }^{29}$ And IOs intended beneficiaries have at times expressed their frustration when IOs speak and act on their behalves. For instance, representatives of poor people walked out of World Bank governance meetings, accusing the Bank of stifling their voices and merely pretending to safeguard the interests of the global poor. ${ }^{30}$ And some 'victims of international crimes' have expressed strong concerns about the ICC's promotion of criminal accountability on their behalf rather than material reparation or political empowerment. ${ }^{31}$

In sum, the governance decisions made by IOs can have significant consequences for their intended beneficiaries' vital interests and political agency. Following the logic of the modified AIP, these potentially positive and negative consequences generate strong normative claims for inclusion. I turn now to examine whether meaningful inclusion of IOs' intended beneficiaries is feasible.

\section{Inclusion as 'Mediated Inclusion'}

Decisions by IOs can affect thousands or even millions of intended beneficiaries, often in multiple countries. This section argues that for such situations of largescale governance, inclusion via processes of representation and communication, or 'mediated inclusion,' is appropriate.

Inclusion can be promoted through a variety of powers available to individuals and groups, including votes, legal standing, vetoes, and organized opposition. ${ }^{32}$ Different mechanisms of inclusion can operate at different sites of governance decision-making, from authorizing leaders, to shaping policy agendas, to developing and implementing policies, to directly challenging decisions that harm particular individuals and groups, to holding actors and institutions to account for past activities. In some cases, inclusion can and should be pursued by direct participation. For instance, it may be important to have mechanisms of direct accountability by which intended beneficiaries can make individual claims for reparation if harmed by an IO. However, for many other decision-

28 A full development of the concept of usurpation and its impact in global governance is beyond the scope of this article. See Chris Tenove, 'Governing in Their Names: Domination, Usurpation and Accountability between IOs and Their Intended Beneficiaries', International Studies Association (Atlanta, GA, 2016).

29 Linda Alcoff, 'The Problem of Speaking for Others', Cultural critique /20 (1991), 5-32; Jane Mansbridge, 'Should Blacks Represent Blacks and Women Represent Women? A Contingent 'Yes”, The Journal of Politics 61/o3 (1999), 628-57.

30 Molly Anders, 'No Easy Path for the World Bank's Safeguards', Devex (2014), <https://www.devex.com/news/noeasy-path-for-the-world-bank-s-safeguards-84887> (Accessed: 8 March 2018).

31 Stephen Smith Cody, 'The Victims' Court?: A Study of 622 Victim Participants at the International Criminal Court', (Berkeley, CA: Human Rights Center, University of California, Berkeley, 2015); Lucy Hovil and Joanna Quinn, 'Peace First, Justice Later: Traditional Justice in Northern Uganda', Refugee Law Project Working Paper (Kampala, Uganda: Refugee Law Project, 2005).

32 Warren (2017), p. 44. 
making processes where inclusion is warranted, such direct inclusion is unfeasible. Representation will often be necessary.

Representation is not just a regrettable substitute for direct participation. Representatives can improve the quality of political judgments, and they can identify, inform and mobilize constituencies of individuals who might not have recognized their shared concerns. ${ }^{33}$ Political representation can also create opportunities for individual participation, such as when representatives engage with constituency members to solicit their opinions and insights. As Plotke observes, 'the opposite of representation is not participation. The opposite of representation is exclusion.' 34

This is not to say that representation necessarily promotes inclusion. Representation can be done poorly, exploitatively or ineffectually. For it to advance inclusion, three components are necessary. First, representatives must make valid claims on behalf of a constituency. Second, representatives must be able to advocate for constituencies in IO decision-making that will significant affect their interests. Third, decision-making must occur with sufficient publicity, so that it may be evaluated and decision-makers held to account.

If constituencies of intended beneficiaries have representatives that can make strong claims on their behalves, if their representatives have significant opportunities to advocate in IO decision-making, and if decision-making is carried out in a sufficiently public manner, then one can say that intended beneficiaries have significant powers of inclusion in IO governance. ${ }^{35}$ In the following three sections I develop these three components of mediated inclusion, and I provide a broad-strokes analysis of empirical studies of their enjoyment by IOs' intended beneficiaries.

\section{Representing Intended Beneficiaries}

Good representatives of IOs' intended beneficiaries can put forward the interests and enhance the agency of the people they represent. Poor representation, by contrast, can lead to harm and to the usurpation of intended beneficiaries' political agency. ${ }^{36}$ The difference between good and bad representation is contested in theory and practice. This section first proposes that intended

33 David Plotke, 'Representation Is Democracy', Constellations 4/1 (1997), 19-34; Michael Saward, The Representative Claim (Oxford: Oxford University Press, 2010).

34 Plotke (1997), p. 19.

35 A full defense and elaboration of mediated inclusion is beyond the scope of this paper. For more see Chris Tenove, 'Justice and Inclusion in Global Politics: Representing and Advocating for Victims of International Crimes', Doctoral Dissertation (Vancouver: University of British Columbia, 2015), <http://circle.ubc.ca/handle/2429/51982> (Accessed: 8 March 2018).

36 For instance, Ludwig observes that refugee organizations often portray refugees as abject and helpless in order secure support from host governments and publics, even though these characteristics are often inapt and can undermine refugees' attempts to pursue employment or political engagement (Bernadette Ludwig, "Wiping the Refugee Dust from My Feet": Advantages and Burdens of Refugee Status and the Refugee Label', International Migration 54/1 (2016), 5-18). 
beneficiaries require representatives that make strong claims to speak for, speak as and speak about them, thereby advancing multiple normative goods for them. It then surveys empirical literature to identify strengths and weaknesses of actors that currently represent intended beneficiaries in IO decision-making: state parties, non-governmental organizations (NGOs), and IO-designated representatives.

\section{Representative Claims to Speak For, As and About}

There is robust normative and empirical debate about political representation, with increasing attention to thelegitimacy of representativeclaims by non-elected actors. ${ }^{37} \mathrm{~A}$ 'representative claim' is both a set of assertions about a particular constituency (such as its interests or values) and a justification, sometimes implicit, for why the audience to the claim should accept the representative's assertions. ${ }^{38}$ Representatives can be evaluated on different normative criteria and can advance different goods for those they represent. I propose three ideal types of representative claims that are important for representing IOs' intended beneficiaries - claims to speak for, speak as and about constituencies (summarized in Table 1). ${ }^{39}$ Any claim can be evaluated on all three dimensions, though in practice different types of actors tend to make stronger claims of one type rather than all three.

For representatives to speak for constituencies, constituency members must exert direct control over who the representatives are and what they say. Such claims can be evaluated by examining opportunities for constituency members to authorize representatives and hold them to account. ${ }^{40}$ Mechanisms of authorization and accountability provide opportunities for individual constituency members to exercise agency over and through their representatives' actions. Elections are a familiar mechanism of authorization (when constituents vote for representatives) and accountability (the opportunity to re-elect or reject a representative in a future elections). But non-electoral mechanisms of authorization and accountability exist in domestic and global politics. ${ }^{41}$ Different mechanisms provide different opportunities for constituency members to exert agency, which in turn leads to stronger or weaker claims by representatives

37 See Macdonald (2008); Laura Montanaro, 'The Democratic Legitimacy of Self-Appointed Representatives', The Journal of Politics 74/4 (2012), 1094-107; Saward (2010).

38 Saward (2010).

39 For a similar typology of representative claims, but which does not clarify the normative goods they advance, see Hugo Slim, 'By What Authority? The Legitimacy and Accountability of Non-Governmental Organisations', The Journal of Humanitarian Assistance 10 (2002).

40 Macdonald (2008); Hanna Pitkin, The Concept of Representation (Berkeley and Los Angeles: University of California Press, 1972).

41 For analyses of authorization and accountability by non-electoral mechanisms, see Ruth Grant and Robert O. Keohane, 'Accountability and Abuses of Power in World Politics', American Political Science Review 99/1 (2005), 29-43; Macdonald (2008); Saward (2010). 


\section{SHOULD INTERNATIONAL ORGANIZATIONS INCLUDE BENEFICIARIES IN DECISION-MAKING? ARGUMENTS FOR MEDIATED INCLUSION}

to speak for them. The greater the active ongoing support by constituency members, the stronger the claim by a representative to speak for them.

TABLE 1: IDEAL TYPES OF REPRESENTATIVE CLAIMS

\begin{tabular}{|c|c|c|}
\hline $\begin{array}{c}\text { TYPE OF } \\
\text { REPRESENTATIVE CLAIM }\end{array}$ & STANDARD OF LEGITIMACY & CONTRIBUTION TO INCLUSION \\
\hline Speak for & $\begin{array}{l}\text { Relational responsiveness to } \\
\text { constituency }\end{array}$ & Agency of constituency members \\
\hline Speak about & Deliberative validity of claim & Epistemic validity of decision \\
\hline Speak as & $\begin{array}{l}\text { Shared identity between } \\
\text { constituency and representative }\end{array}$ & $\begin{array}{l}\text { Recognition of constituency } \\
\text { members }\end{array}$ \\
\hline
\end{tabular}

The claim to speak about a constituency is valid or not depending on the epistemic quality of the claim rather than the representative's relationship to the constituency. Claims to speak about a constituency should be evaluated on deliberative criteria, in which they are assessed with competing claims in processes committed to reasonableness, mutual justifiability and noncoercion. ${ }^{42}$ High quality claims to speak about constituencies can be information rich and relevant to policymaking. When unmoored from mechanisms of authorization and accountability, however, claims to speak about a constituency can be problematic, generating the familiar dangers of voice appropriation and technocracy.

Finally, representatives can speak as a member of the constituency being represented. People are regularly asked to speak on behalf of those who share aspects of identity or important experiences, often referred to as 'descriptive representation.'43 The legitimacy of claims to speak as are based on representatives' authenticity as constituency members and the extent to which other members identify with them. Representatives who speak as members of a social group can promote the recognition of constituency members, both in the eyes of the constituency and in the eyes of a larger community. ${ }^{44}$ This is particularly important for social groups that have suffered from marginalization and exclusion. Furthermore, members of a social group may have important insights about a group's predicament that non-members are unlikely to possess. Representatives who speak as members of a constituency can also claim to speak for it (by being authorized and accountable) or speak about it (through the epistemic strength of their claims).

For constituencies of intended beneficiaries to be well represented, they

42 For different but overlapping accounts of deliberative legitimacy, see Jürgen Habermas, Between Facts and Norms: Contributions to a Discourse Theory of Law and Democracy (Cambridge, MA: MIT Press, 1996); Young (2000).

43 Pitkin (1972).

44 Alcoff (1991); Mansbridge (1999). 
will usually require multiple representatives who can make different types of representative claims and therefore advance all three sets of normative goods for the constituencies in question. Constituencies need opportunities to exert their agency through representatives who speak for them. They frequently need advocates with expert knowledge to propose how the constituency's interests can be promoted in complex policy areas. They may also require representatives who can speak as members of their constituency to promote trust in an IO or recognition through its actions. Moreover, multiple representatives are needed in order to advocate for diverse groups and values within a constituency, and to challenge, improve or complement the claims made by representatives. Constituencies will thus be better represented when they have multiple and competing representatives, rather than a single ideal representative.

Furthermore, there can be quite different kinds of constituencies that need representation. Some IO decision-making processes affect very narrow and concrete constituencies, such as the residents of a particular refugee camp, or inhabitants of communities that may be affected by a dam funded by the World Bank. For such decision-making processes, it is feasible to have representatives who can make strong claims to speak for or as constituency members. By contrast, some decision-making processes may affect millions of people in diverse settings, or may constitute whole categories of intended beneficiaries (such as the negotiations to create them 1951 Convention Relating to the Status of Refugees). In such cases, claims to speak about the constituency must often predominate.

Inclusion thus needs to be promoted by different forms of representation for decision-making processes with different scopes. When decisions affect extremely large, diverse or hypothetical groups, representation can be understood as claims made in a 'conversation' over time. As Young argues, this conversation model sees representation as a relationship between representatives and constituency members, in which there are 'moments' when constituency members can authorize or hold to account their representatives. ${ }^{45}$ This ongoing conversation makes it possible for representatives to put forward views and interests of IOs' intended beneficiaries, and for members of these groups to support, reject, or seek to alter claims made on their behalves.

\section{Who Can Represent Intended Beneficiaries?}

For intended beneficiaries to be included in IO decision-making, they need actors to make valid representative claims on their behalf. Who can legitimately do so? Scholarship on IOs has put forward a variety of actor types. This section

45 Young (2000), 125-133. 
briefly assesses the opportunities and limitations for representative claimmaking about intended beneficiaries by state governments, non-governmental organizations, and officials that IOs institutionally-designate to speak on intended beneficiaries' behalves.

\section{State governments}

Much IR scholarship assumes that only state governments can legitimately represent populations in IO governance. ${ }^{46}$ However, in many cases state governments will be poor representatives of IOs' intended beneficiaries. People often come to be refugees, victims of international crimes, and other categories of intended beneficiaries, because of a broken political relationship with their state government. Predatory states and fragile states often cannot credibly represent the interests of their own citizens. Furthermore, foreign governments are unlikely to strongly or consistently represent populations of IOs' intended beneficiaries, since both democratic and undemocratic governments tend to seriously discount the interests of non-citizens. ${ }^{47}$ State governments will therefore tend to make weak representative claims to speakfor or as IOs intended beneficiaries. There are exceptions, however. For instance, in deliberations at the UN in April 2017, Canada's Minister for Immigration, Refugees and Citizenship stated:

I speak to you not only as the representative of a country whose history has been shaped by generations of immigrants, but also as someone whose own life has been shaped by the experience of migration. I first came to Canada as a 16-year-old asylum seeker, and so I'm informed by my personal experiences. ${ }^{48}$

\section{Non-governmental organizations}

Many commentators have argued that civil society actors - and NGOs in particular - can best represent those affected by global governance, and in particular be the voice of 'those marginalized groups of stakeholders that face the greatest obstacles to political participation. ${ }^{49}$ As the number, influence and governing activity of NGOs has increased, however, so have questions about

46 This is referred to as the 'state consent' model in Allen Buchanan and Robert O. Keohane, 'The Legitimacy of Global Governance Institutions', Ethics \& International Affairs 20/04 (2011), 405-37.

47 Buchanan and Keohane (2011), p. 414-18.

48 Ahmed Hussen, 'Statement of the Honourable Ahmed Hussen, Minister of Immigration, Refugees and Citizenship: Panel Discussion Hosted by the International Organization for Migration', (New York: United Nations, 2017), $<$ https://www.iom.int/international-dialogue-migration-2017-strengthening-international-cooperation-andgovernance> (Accessed: 8 March 2018).

49 Patrizia Nanz and Jens Steffek, 'Global Governance, Participation and the Public Sphere', Government and Opposition 39/2 (2004), 314-35, 334 . 
their legitimacy as representatives. ${ }^{50}$

Scholarship on NGOs as representatives in global governance is extensive, but often uses fuzzy or narrow conceptions of representation. ${ }^{51}$ Nevertheless, recent literature identifies several factors that shape the quality of representative claims that NGOs may make on behalf of IOs' intended beneficiaries.

First, NGOs with different functional roles will have different capacities to make representative claims on behalf of intended beneficiaries. While some NGOs primarily deliver services, others advocate for ideologies or causes, and still others advocate for specific constituencies. ${ }^{52}$ Only NGOs that advocate for particular constituencies of intended beneficiaries are likely to make strong representative claims to speak for them. Service-oriented organizations and advocates of principles may make strong claims to speak about policies that can advance particular goods for constituencies, but they may be unresponsive to people's expressed preferences. Some civil society organizations can support constituencies so that their members have greater opportunities to speak as representatives. For instance, an organization like the Green Belt Movement in Kenya promotes the capacity of rural women to mobilize within and beyond their communities on social and environmental issues. ${ }^{53}$

Second, NGO funders and funding mechanisms can influence their relationships with constituencies of concern and thus shape the quality of their representation. ${ }^{54}$ For instance, the interests of constituencies from the global South often receive less attention, since most funding comes from donors in the North. ${ }^{55}$ Competition for funding can lead to conflicts between NGOs' financial security and the needs or desires of constituencies they aim to represent or assist. ${ }^{56}$

50 Steve Charnovitz, 'Accountability of Non-Governmental Organizations in Global Governance', in Lisa Jordan and Peter van Tuijl, (eds.), NGO Accountability: Politics, Principles and Innovations (London: Earthscan, 2006), 2142; Jennifer C. Rubenstein, 'The Misuse of Power, Not Bad Representation: Why It Is Beside the Point That No One Elected Oxfam', Journal of Political Philosophy 22/2 (2014), 204-30; Slim (2002).

51 Though see Rubenstein (2014); Jonas Tallberg and Anders Uhlin, 'Civil Society and Global Democracy: An Assessment', in Daniele Archibugi, Mathias Koenig-Archibugi, and Raffaele Marchetti, (eds.), Global Democracy: Normative and Empirical Perspectives (Cambridge: Cambridge University Press, 2012), 210-32.

52 Clifford Bob, The Marketing of Rebellion: Insurgents, Media, and International Activism (Cambridge: Cambridge University Press, 2005); L David Brown, Alnoor Ebrahim, and Srilatha Batliwala, 'Governing International Advocacy NGOs', World Development 40/6 (2012), 1098-108; Hahn (2010) In practice, there is often blurring of these functional roles.

53 Marc Michaelson, 'Wangari Maathai and Kenya's Green Belt Movement: Exploring the Evolution and Potentialities of Consensus Movement Mobilization', Social Problems (1994), 540-61.

54 Key studies include Bob (2005); Brown, Ebrahim, and Batliwala (2012); Alexander Cooley and James Ron, 'The NGO Scramble: Organizational Insecurity and the Political Economy of Transnational Action', International Security 27/1 (2002), 5-39; Scholte (2011).

55 Bob (2005); Tanja Brühl, 'Representing the People? NGOs in International Negotiations', in Jens Steffek and Kristina Hahn, (eds.), Evaluating Transnational NGOs: Legitimacy, Accountability, Representation (New York: Palgrave Macmillan, 2010), 181-99.

56 Brühl (2010); Cooley and Ron (2002). 
Third, NGOs' organizational structure and internal governance practices can shape their relationships to constituencies. For instance, international NGOs that are federations of constituency-based subunits can make strong claims to speak for constituencies. As an example, Shack/Slum Dwellers International is a federation of national associations of people who advocate for - and often belong to - poor urban communities, and these national associations elect the members of the NGO's governing board. ${ }^{57}$ This also means that many of the NGOs' leaders can speak as members of its constituency of concern. By contrast, many international NGOs do not have members of the constituencies they serve in senior organizational positions, limiting their capacity to claim to speak as these constituencies.

These and other findings suggest that the quality of representative claims by NGOs will often have some weaknesses. However, the quality of representation by NGOs has received increasing scrutiny by communities, donors, IOs, and NGOs themselves. Many international NGOs have made institutional efforts to improve their capacities to speak for and as communities of beneficiaries. As Tallberg and Uhlin argue, despite their weaknesses, NGOs can often make stronger representative claims for intended beneficiaries than states, corporations, and most other actors in global governance..$^{8}$

\section{Institutionally-designated representatives}

In addition to actors outside an IO who push to advocate for intended beneficiaries, some IOs officially designate actors to be the representatives of beneficiary groups. A wide range of institutionally-designated representatives of intended beneficiaries can be seen in IOs today. For instance, one of the 20 voting positions on the governing board of the Global Fund to Fight AIDS, Tuberculosis and Malaria (GFATM) is designated for a representative of individuals affected by HIV/AIDS, tuberculosis or malaria. The UN SecretaryGeneral regularly appoints Special Envoys and Special Representatives, some of who advocate for particular categories of intended beneficiaries. ${ }^{59}$ As another example, the ICC funds and assists lawyers to act as representatives of victims of crimes in judicial proceedings.

Such institutionally-designated representatives can have positive or negative effects on the inclusion of intended beneficiaries. They may have greater influence on IOs than civil society groups because of their formal standing in decisionmaking processes. However, they may make poor quality representative claims

57 Brown, Ebrahim, and Batliwala (2012).

58 Tallberg and Uhlin (2012), p. 226-8.

59 Examples include the UN Secretary-General's Special Representative for Children and Armed Conflict, the Special Representative on the Human Rights of Internally-Displaced Persons, and the Special Envoy for people with HIV/ AIDS in Africa. 
if they are primarily authorized by and accountable to the IO that employs them, and not necessarily to the constituency they represent. They may also lack qualities of identity or expertise needed to make strong claims to speak as or speak about constituencies. The institutional designation of representatives is an interesting experiment in IO design, but to date there is little empirical analysis of their representative claims or their impact on inclusion.

\section{Opportunities for Advocacy in IO Decision-making Processes}

To promote the inclusion of intended beneficiaries, their representatives must have adequate opportunities for advocacy in IO decision-making processes that affect them, which includes both access to relevant decision-making processes and that their claims receive due consideration. Of course, the representatives of intended beneficiaries should not single-handedly determine decision outcomes. The interests and perspectives of other constituencies must be taken into consideration, and IOs face limitations due to their resources, mandates and operating environments. However, representatives of intended beneficiaries should be able to participate in deliberations about how to accommodate or question these factors, propose alternative actions and demand justifications for decisions made.

According to some understandings of international politics, meaningful advocacy by representatives of intended beneficiaries is entirely utopian. On this view, states make all significant decisions about IOs' behavior, and other actors lack opportunities and power to influence decision outcomes.

However, while state governments are the key players, two lines of empirical research suggest that meaningful advocacy for intended beneficiaries is possible. First, access by NGOs and other non-state actors to IO decision-making has increased substantially in recent decades, and some IOs have granted significant access to institutionally-designated representatives. Second, the design of decision-making processes can improve opportunities for 'weaker' actors to receive due consideration, including by making decision-making processes more conducive to 'arguing' rather than coercion and bargaining among decision-makers. Research on these factors suggests practices and conditions that might yield more meaningful opportunities for advocacy on behalf of intended beneficiaries.

\section{Access by Non-state Actors to IO decision-making}

In recent decades, non-state actors have gained greater access to IO decisionmaking, creating opportunities for them to advocate for IOs' intended beneficiaries. In particular, civil society actors have played an increasing role in both inter-state negotiations and IO decision-making. A convincing case for 
this 'opening up' of IOs to non-state actors has been put forward by Tallberg and co-authors. ${ }^{60}$ Looking at 50 international organizations and 298 sub-bodies between 1950 to 2010, they find that increased access by non-state actors to IO decision-making 'pervades all issue areas, all policy functions, and all world regions.' 61

This access exists on a continuum, ${ }^{62}$ which includes:

- Full participation. Non-state actors can contribute to all relevant decisions. This usually takes the form of a seat on governing boards of IOs. This is rare for non-state actors, but does exist. For instance, the GFATM governing board has a voting position for a representative of people affected by HIV/Aids, tuberculosis or malaria, and International Labour Organization's governing body has 14 representatives of workers, along with 14 representatives of employers and 28 representatives of state governments.

- Partial participation. Non-state actors are guaranteed the opportunity to formally engage in a sub-set of decision-making processes. Their contribution is often limited to the design or implementation of particular policies or projects. For instance, some international tribunals and secretariats allow individuals or NGOs to submit complaints and pursue legal action on them.

- Consultation. Non-state actors are invited, at the discretion of decision-makers, to contribute to particular decision-making processes. Their contribution is often limited to providing information rather than acting as a decision-maker. Consultation is often channeled through IOs' civil society advisory bodies. For instance, over 3,500 NGOs have been granted 'consultative status' by the UN's Economic and Social Council, and can attend and speak during meetings. ${ }^{63}$

- Observation. Non-state actors can scrutinize decision-making but cannot contribute to it. Observation may occur through physical attendance during a decision-making processes, or through guaranteed access to records of it. For instance, the UN Framework Convention on Climate Change allows non-state actors

6o Jonas Tallberg, Thomas Sommerer, and Theresa Squatrito, The Opening up of International Organizations: Transnational Access in Global Governance (Cambridge: Cambridge University Press, 2013).

61 Tallberg, Sommerer, and Squatrito (2013), p. 2.

62 This typology is similar to one put forward by Christer Jönsson and Jonas Tallberg, Transnational Actors in Global Governance: Patterns, Explanations, and Implications (New York: Palgrave Macmillan, 2010), p. 5-8.

63 Kerstin Martens, 'Civil Society and Accountability of the United Nations', in Jan Aart Scholte, (ed.) Building Global Democracy?: Civil Society and Accountable Global Governance (Cambridge: Cambridge University Press, 2011), 42-57. 
to observe meetings of the Conferences of the Parties, and to make interventions at the discretion of the chairperson.

- No access. Non-state actors cannot observe or contribute to decision-making. Decision-makers may later release information about decision-making, at their own discretion.

Several factors influence the level of access that civil society organizations and other non-state actors have to IO decision-making. These include the extent to which IOs need these non-state actors to govern effectively (such as for implementing community development projects or monitoring human rights performance); ${ }^{64}$ the policy area the IO oversees (for instance, states resist access in IO decision-making that impacts national security), ${ }^{65}$ and a history of strong pressure by civil society for access, such as occurred at the United Nations and World Bank. 66

International organizations may also play a gatekeeping role and selectively include or exclude certain types of NGOs. For instance, some IOs allow states to deny access to NGOs (including critical NGOs). ${ }^{67}$ Studies have found systematic discrimination against participation at the IMF and World Bank by those civil society groups that are based in the global South, that challenge market-based economic development, or that focus on issues such as land rights or access to food. ${ }^{68}$ Such gatekeeping over access has important implications for the inclusion of intended beneficiaries, as it may incentivize actors to make claims more palatable or desirable to the IO bureaucracy or state parties.

Taken together, these and other findings have several implications for advocacy for intended beneficiaries. There is a general trend toward increased openness in global governance decision-making, though most access leads to contributions of restricted scope. Civil society organizations are rarely guaranteed full or partial participation in decision-making. For that reason, advocacy by institutionally-designated representatives of intended beneficiaries may often be advantageous. Finally, even when civil society representatives of intended beneficiaries have access, they may not have influence, since they usually lack

64 Jens Steffek, 'Explaining Patterns of Transnational Participation: The Role of Policy Fields', in Christer Jönsson and Jonas Tallberg, (eds.), Transnational Actors in Global Governance: Patterns, Explanations, and Implications (New York: Palgrave Macmillan, 2010), 67-87; Tallberg, Sommerer, and Squatrito (2013).

65 Steffek (2010); Tallberg, Sommerer, and Squatrito (2013).

66 Alnoor Ebrahim and Steven Herz, 'The World Bank and Democratic Accountability: The Role of Civil Society', in Jan Aart Scholte, (ed.) Building Global Democracy?: Civil Society and Accountable Global Governance (Cambridge: Cambridge University Press, 2011), 58-77; Martens (2011).

67 For instance, China and Cuba have used their positions on the NGO Committee to exclude NGOs that are critical of their policies (Martens (2011), p. 48).

68 Ebrahim and Herz (2011); Ngaire Woods, 'Multilateralism and Building Stronger International Institutions', in Alnoor Ebrahim and Edward Weisband, (eds.), Global Accountabilities : Participation, Pluralism, and Public Ethics (Cambridge: Cambridge University Press, 2007), 27-44 


\section{SHOULD INTERNATIONAL ORGANIZATIONS INCLUDE BENEFICIARIES IN DECISION-MAKING? ARGUMENTS FOR MEDIATED INCLUSION}

the bargaining power or coercive capacities of states. The next section looks at how representatives may nevertheless receive due consideration in IO decisionmaking.

\section{Improving consideration: formal status and opportunities for arguing}

For representatives of intended beneficiaries to contribute to decision-making, they not only require access to decision-making processes but decision-makers must give due consideration to their claims. However, representatives of IOs' intended beneficiaries will frequently have fewer resources for incentivizing or coercing other actors to consider and accommodate their positions. Two elements of IO design can significantly improve consideration of these representatives' claims: formal participatory status, and decision-making processes designed to be more responsive to 'arguing' rather than 'bargaining.'

First, some IOs not only give representatives of intended beneficiaries the opportunity to be present and to give voice in decision-making, they also provide them with formal status that ensures their views must be considered. For instance, representatives can be given a vote in the decision-making process. At the GFATM, a representative of communities affected by HIV/AIDS, tuberculosis or malaria holds one of the 20 voting positions on the organization's global governing board. There are additional voting positions for representatives of civil society from developed and developing countries. The formal participation of civil society in GFATM decision-making has significantly improved its transparency and its responsiveness to some affected constituencies. ${ }^{69}$

Second, representatives of intended beneficiaries may have more influence in decision-making processes where the outcomes are more significantly determined by the moral and epistemic force of claims, and not by the mobilization of material resources. These different forms of interaction among decision-makers have often been referred to as 'arguing' and 'bargaining.' When decision-making processes follow the 'logic of arguing,' as Risse calls it, actors engage in processes of reason-giving and may be persuaded to change their preferences. ${ }^{70}$ Several factors have been identified that make it more likely for arguing to make a significant contribution to inter-state negotiations and IO decision-making. Certain institutional norms can encourage arguing over bargaining, such as having a neutral chairperson, or increasing the transparency

69 Carolyn Long and Nata Duvvury, 'Civil Society and Accountability Promotion in the Global Fund', in Jan Aart Scholte, (ed.) Building Global Democracy?: Civil Society and Accountable Global Governance (Cambridge: Cambridge University Press, 2011), 245-66.

70 Thomas Risse, '"Let's Argue!”: Communicative Action in World Politics', International Organization 54/o1 (2000), 1-39. 
of some decision-making processes. ${ }^{71}$ Certain phases of negotiations may be more amenable to arguing, such as early in negotiations when the agenda is uncertain and participants are developing 'common knowledge' about issues, ${ }^{72}$ or at moments in negotiations when new knowledge or new normative arguments cause a re-framing of issues. ${ }^{73}$ Legal processes may be more conducive to a logic of arguing, ${ }^{74}$ though they may also be used as a means to prevent certain actors and arguments from being made. ${ }^{75}$

Studies of IO decision-making have thus identified factors that can improve opportunities for the inclusion of intended beneficiaries: by the extent to which these processes are 'opened up' to non-state actors that might represent these constituencies, by the presence or absence of formal participation rights given to these representatives, and by factors that encourage deliberation in decisionmaking processes. In practice, these factors vary significantly among IOs, and often yield unsatisfactory opportunities for advocacy. Nevertheless, the trend towards greater openness of IOs to non-state actors, and the examples of experimentation by IOs in institutional mechanisms that enhance opportunities for advocacy by representatives of intended beneficiaries, suggest that further improvements are possible.

\section{Expanding Publicity of IOs: Transparency and Public Awareness}

The third element of mediated inclusion is publicity. Publicity exposes decisionmakers to criticism and accountability, and it can reveal positions that are self-interested, false or otherwise unjustifiable to broader publics. ${ }^{76}$ Members of constituencies of intended beneficiaries need opportunities to learn what happened in decision-making processes to assess the acceptability of the process and its outcomes. To achieve these goods, two elements of publicity are necessary: transparency and public awareness.

\section{Transparency and Its Limits}

Transparency means that those not party to decision-making processes have enough information to assess them. Only by knowing what institutions do, and how they came to do it, can decision-making be held to account or

71 Thomas Risse and Mareike Kleine, 'Deliberation in Negotiations', Journal of European public policy 17/5 (2010), 708-26; Cornelia Ulbert, Thomas Risse, and Harald Müller, 'Arguing and Bargaining in Multilateral Negotiations', Conference on "Empirical Approaches to Deliberative Politics" (2004).

72 Risse (2000).

73 Nicole Deitelhoff, 'The Discursive Process of Legalization: Charting Islands of Persuasion in the ICC Case', International Organization 63/01 (2009), 33-65; Risse and Kleine (2010); Ulbert, Risse, and Müller (2004).

74 Ian Johnstone, The Power of Deliberation: International Law, Politics and Organizations (Oxford: Oxford University Press, 2011).

75 Ian Hurd, 'Law and the Practice of Diplomacy', International Journal 66/Summer (2011), 581-96.

76 Publicity is thus widely seen as necessary for democratic governance Habermas (1996); Young (2000). 
awarded legitimacy. ${ }^{77}$ It is not expected that all people will seek to do so, but constituency representatives and some constituency members ought to have that opportunity. To assess transparency, we do not simply look at the amount of information provided. Instead, we look at who has access to information, and whether particular actors can access the kinds of information they need to evaluate decision-making and hold decision-makers to account. ${ }^{78}$

Scholars have identified a transparency norm in global governance that became prominent in the 1990 s and has largely continued. ${ }^{79}$ Transparency in inter-state and IO decision-making has improved in several ways: by giving outside actors - especially civil society organizations - greater access to decision-making processes; through increased publication of information about the policies, procedures and findings of IOs; and through the adoption by IOs of access to information policies.

Examples of improved transparency are widespread. For instance, until the early 1990 s the IMF only provided information about its policies to a restricted group of central bankers and finance ministry staff. It now puts considerable information online, makes public most of its policy papers, and uses outreach staff to engage civil society actors and broader publics. ${ }^{80}$ The World Bank, too, makes public much of its research and policy analysis, engages extensively with civil society, and introduces transparency measures so that intended beneficiaries can evaluate the actions of service providers. ${ }^{81}$

However, there are two ways in which this transparency norm may not benefit IOs' intended beneficiaries. First, much of the information put forward by IOs is not particularly useful in promoting accountability. Fox notes that, in the area of economic development, there is considerable 'fuzzy transparency,' which 'involves the dissemination of information that does not reveal how institutions actually behave in practice, whether in terms of how they make decisions, or the results of their actions. ${ }^{82}$ Furthermore, transparency has little consequence if it is not accompanied by means to sanction or influence decision-makers.

77 Grant and Keohane (2005); Jan Aart Scholte, 'Global Governance, Accountability and Civil Society', in Jan Aart Scholte, (ed.) Building Global Democracy?: Civil Society and Accountable Global Governance (Cambridge: Cambridge University Press, 2011), 8-41.

78 Alexandru Grigorescu, 'Transparency of Intergovernmental Organizations: The Roles of Member States, International Bureaucracies and Nongovernmental Organizations', International Studies Quarterly 51/3 (2007), 625-48.

79 Ann Florini, 'The Right to Know: Transparency for an Open World', (New York: Columbia University Press, 2007); Rodger A. Payne and Nayef H. Samhat, Democratizing Global Politics: Discourse Norms, International Regimes, and Political Community (Albany: State University of New York Press, 2004).

80 Barnett and Finnemore (2004), p. 45-72.

81 John Gaventa and Rosemary McGee, 'The Impact of Transparency and Accountability Initiatives', Development Policy Review 31 (2013), s3-s28; Payne and Samhat (2004).

82 Jonathan Fox, 'The Uncertain Relationship between Transparency and Accountability', Development in Practice 17/4-5 (2007), 663-71, p. 667 
Second, despite a general shift toward greater transparency, some decisionmaking processes and some institutions remain opaque. For instance, crucial decisions by states at the World Bank, IMF and WTO are sometimes negotiated behind closed doors. ${ }^{83}$ At the WTO, many formal decision-making processes are open to scrutiny by civil society, but key decisions during Ministerial Conferences are made by a small number of major states in confidential 'green room' consultations. Furthermore, some IOs lack the institutional capacity needed to achieve transparency levels they have committed to. ${ }^{84}$

Limits to transparency can sometimes be justified, such as when information might harm people or compromise institutional functions. For instance, international criminal tribunals must withhold details about investigations to protect witnesses, and security IOs must keep details confidential to prevent their exploitation by possible attackers. Furthermore, deliberation may sometimes be improved by limiting transparency, because participants are more willing to explain their reasons and change their minds without the glare of public exposure. ${ }^{85}$ We thus need to be aware of possible costs of transparency. But insiders' arguments for confidentiality deserve to be treated with some skepticism. Scholte thus argues that 'the default position [ought to be] timely and full disclosure, and any exceptions to that rule require thorough justification. ${ }^{86}$

\section{Public Awareness by Intended Beneficiaries}

Public awareness means that people will be alerted to governance decisions that will significantly affect their lives. In large-scale governance, it is not expected that all individuals affected by decisions will be well informed about them. However, people should be part of systems of communication that enable them to become aware of decisions that will have a significant and possibly negative impact on them or their communities.

This information can come through many channels, including news media, outreach by governance agencies, civil society organizations and discussion among individuals about governance matters. Dramatic improvements in information and communication technologies (ICTs) in recent years have expanded possibilities for public awareness about IOs. While access to the internet and digital devices was first prominent in wealthier countries, access in poorer countries and among poorer demographic groups is increasing rapidly. ${ }^{87}$

83 Brühl (2010); Woods (2007).

84 Grigorescu (2007).

85 Jeffrey Lewis, 'How Institutional Environments Facilitate Co-Operative Negotiation Styles in EU Decision-Making', Journal of European Public Policy 17/5 (2010), 648-64.

86 Scholte (2011), 17.

87 James B Pick and Avijit Sarkar, The Global Digital Divides: Explaining Change (Heidelberg: Springer, 2015). 
Divides in information access remain, with divisions along lines such as wealth, gender, ethnicity and geographical location. The intended beneficiaries of global governance are particularly likely to have limited access to ICTs.

International organizations frequently pursue information campaigns to shape the behaviour of their intended beneficiaries, and these campaigns are well-studied in fields such public health. ${ }^{88}$ Civil society groups and IOs regularly administer public opinion surveys to intended beneficiaries, which assess the level of knowledge that intended beneficiaries have about IOs and the services they deliver. For instance, the World Bank surveys recipients of different forms of assistance and sometimes publishes their opinions. ${ }^{89}$ However, we lack empirical research that compares public awareness of intended beneficiaries across IOs and global governance regimes, which might shed more light on practices or conditions that best promote awareness.

\section{Conclusion}

International organizations can advance both advance or undermine the agency and interests of their intended beneficiaries, generating strong normative claims for the inclusion of intended beneficiaries in IO decision-making. Given the scale and complexity of IO governance, this inclusion will often be achieved through representation. The empirical literature on IOs reveals many obstacles and challenges to robust claim-making and opportunities for advocacy by their representatives, as well as to the publicity of IO decision-making. However, the trends at IOs are generally positive. There is increasing attention to the quality of representation of intended beneficiaries by IOs and civil society organizations. There have been significant increases in access to IO decision-making by civil society groups and other actors that can represent constituencies of intended beneficiaries. The transparency of IO decision-making, and efforts by IOs to communicate with beneficiary populations, is generally improving. Moreover, there is significant experimentation at IOs in mechanisms to improve the inclusion of intended beneficiaries, such as the creation of institutionallydesignated representatives or the development of new forms of consultation and communication using digital communication systems.

Further research on these trends, and their variation across IOs, is warranted. The intended beneficiaries of IOs certainly face obstacles and uncertainty in the pursuit of inclusion. Nevertheless, the positive trends and institutional experimentation suggest that the meaningful inclusion of IOs' intended

88 Muhiuddin Haider, 'Global Public Health Communication: Challenges, Perspectives, and Strategies', (Sudbury, MA: Jones \& Bartlett Publishers, 2005)

89 Access to opinion surveys on the views of the World Bank's clients, partners, and other stakeholders can be found at http://countrysurveys.worldbank.org (Accessed: 8 March 2018). 
beneficiaries in decision-making is a feasible aim. This empirical argument provides some support for the use of the affected interests principle. As this paper has argued, the AIP can be used to identify particular categories of affected persons who can make particularly strong normative claims to inclusion-in this case, IOs' intended beneficiaries. The empirical analysis of IOs' relationships with intended beneficiaries has suggested that this inclusion is not infeasible, as some critics of AIP have proposed.

While this paper argues for greater inclusion by IOs of intended beneficiaries and other groups that can make strong normative claims, there can be tradeoffs between inclusion and other normative goods. For instance, institutional efficacy and output legitimacy may be overly reduced if too much emphasis is placed on processes of inclusion. Too much responsiveness to intended beneficiaries might undermine fairness or legality at some IOs-for instance, if international criminal tribunals were to decide trials based on victims' desires rather than fair trial processes. The appropriate balance between inclusion and other principles will be complex and contested.

Nevertheless, the AIP remains a valuable approach to diagnosing democratic deficits of IOs. It focuses our attention on those people who may be excluded from decisions that shape their lives, and whose capacity to address their own problems may be blunted or appropriated. The principle should therefore inform further institutional experiments and further political struggles to advance inclusion in global governance..$^{90}$

Chris Tenove

Postdoctoral Research Fellow

Department of Political Science

University of British Columbia

Email:cjtenove@mail.ubc.ca.

\section{- the global justicenetwork}

90 I would like to thank two anonymous reviewers for their comments. For their suggestions during this paper's development, thanks to Agustin Goenaga, Stewart Prest, Jonathan Tomm, Richard Price, and Mark Warren. An earlier version of this paper was presented at the International Studies Association annual conference. 